\title{
The Influence of Banking Risk on Efficiency: The Moderating Role of Inflation Rate
}

\section{Amalia Ilmiani*, \& Meliza}

Fakultas Ekonomi dan Bisnis, Universitas Pekalongan, Pekalongan, Indonesia

* amaliakartono.m@gmail.com

\begin{tabular}{ll}
\hline Article Info & Abstract \\
\hline $\begin{array}{l}\text { Received : 2021-05-29 } \\
\text { Accepted }: 2022-01-25\end{array}$ & $\begin{array}{l}\text { The increasing business activities of state-owned banks in Indonesia } \\
\text { increases risks. This circumstance can impact the level of state- } \\
\text { owned banks' efficiency. Thus, this research analyses the influence } \\
\text { of banking risks on the state-owned banks' efficiency in Indonesia } \\
\text { from 2016 to 2019. Moreover, inflation as one of the } \\
\text { Key words: credit risk; } \\
\text { macroeconomic factors may also affect the relationship between } \\
\text { banking risks and efficiency; hence, this research also examines the } \\
\text { inflation role as a moderating variable of this relationship. The } \\
\text { samples of this research are all state-owned banks in Indonesia. } \\
\text { Ordinary Least Squares (OLS) regression analysis shows that } \\
\text { liquidity risk and credit risk have positive and significant influences } \\
\text { on efficiency. However, inflation as a moderating variable has no } \\
\text { significant influence on efficiency. Inflation also fails to moderate } \\
\text { the relationship between liquidity risk and efficiency of state-owned } \\
\text { banks in Indonesia. Nevertheless, inflation successful moderates the } \\
\text { relationship between credit risk and efficiency. }\end{array}$ \\
&
\end{tabular}

\section{INTRODUCTION}

State-owned banks operating expenses to operating revenue increased from $72.58 \%$ in 2015 to $76.39 \%$ at the end of 2019 (Indonesia Financial Service Authority, 2019). The increase shows a decrease in commercial banks' efficiency from 2015 to 2019. Efficiency is an essential indicator for banks' performance because it describes to what extent banks can utilise their input to obtain the optimal output. Therefore, a decrease in efficiency indicates a decrease in banks' capability not only in managing their input consisting of deposit funds, assets, and labour but also in generating optimal output, such as loans and investments.

Nowadays, state-owned banks activities tend to increase, especially in funds and distributing these funds to their borrowers. According to Indonesia Financial Service Authority (2019), the number of state-owned banks' deposit funds increased about $48 \%$ from Rp 1,734,961 (in billion rupiahs) in 2015 to $\mathrm{Rp} 2,581,349$ (in billion rupiahs) in 2019. Meanwhile, the fund's distribution also increased about 58\% from Rp 1,536,852 (in billion rupiahs) in 2015 to $\mathrm{Rp} 2,430,773$ (in billion rupiahs) in 2019. Allocating deposit funds into loans and some investments may generate some risks. These risks may occur because deposit funds are shortterm funds and have a maturity of no more than one year. On the other hand, most banks' loans and investments have more than one year of maturity. Therefore, banks may face liquidity risk problems because they have to fulfil their short-term obligation using their long-term fund allocation. According to Indonesia Financial Service Authority (2019), the loan to deposit ratio of state-owned banks in Indonesia increased from $88.58 \%$ in 2015 to $94,17 \%$ at the end of 2019. The increase indicates an increase in liquidity risk of state-owned banks in Indonesia from 2015 to 2019. Hence, an increase in liquidity risk may increase banks expenses and decrease their efficiency.

Besides liquidity risk, an increase in loan distribution may also increase credit risk. An increase in the number of loan distribution and other earning assets may increase the number of non-performing earning assets and non-performing loans. According to Indonesia Financial 
Service Authority (2019), the number of commercial banks earning assets increased about $57.9 \%$ from $\mathrm{Rp} 2,040,597$ (in billion rupiahs) in 2015 to Rp 3,224,071 (in billion rupiahs) in 2019. On the other hand, the number of non-performing assets of state-owned banks also increased by about $22.77 \%$ from 2015 to 2019. An increase in the number of non-performing loans leads banks to increase their monitoring of their borrowers. This circumstance will increase banks' monitoring costs and eventually increase operating expenses. Furthermore, an increase in banks' operating expenses may decrease banks' operating revenue. As a result, this circumstance will decrease banks' efficiency.

Besides liquidity and credit risks, macroeconomics factors may also influence banks' risks and performance. Inflation as one of the macroeconomic factors may influence both banks' deposit and lending rates. Changes in deposit and lending rates may influence banks' risks, while an increase in the inflation rate will increase banks' deposit rates. As a result, an increase in the deposit rates increases lending rates, and it may cause many borrowers to fail to pay back their loans. As a result, banks' credit risk will increase. Thus, inflation can influence banks' risks (Sengkey et al., 2018; Fakhrunas, 2019; Harapan and Alam, 2020). Furthermore, inflation can also affect banks' efficiency (Agade, 2012; Raphael, 2013; Sufian and Kamarudin, 2015). Inflation rate fluctuation may influence banks' deposit and lending rates. Thus, changes in banks' deposit and lending rates may affect banks' operating expenses and operating revenue.

This research analyses the influence of banking risks consisting of liquidity and credit risks on efficiency in Indonesian state-owned banks from 2016 to 2019. Many previous studies have discussed the effect of banking risks on efficiency (Mohd Amin et al., 2019; Le, 2018; Li et al., 2021; Salim et al., 2016; Sarkar et al., 2019; Tan and Anchor, 2017). Moreover, inflation rates are a crucial macroeconomic factor for banks because they influence banks' deposit and lending rates. Previous studies concerning the influence of inflation on banking risks and the effect of inflation on efficiency have also been initiated by many researchers (Agade, 2014; Fakhrunnas, 2019; Kadar et al., 2016; Koju et al., 2018; Wiryono \& Effendi, 2018). Meanwhile, few studies discussed the relationship between banking risks and efficiency using the inflation rate as a moderator. However, only a few studies have discussed the effect of banking risks on efficiency using inflation as a moderating variable. Therefore, this research contributes to employing inflation as a moderator of the relationship between banking risks and efficiency.

This research can guide state-owned banks in Indonesia to minimise their risks and maximise their efficiency. Moreover, this research contributes to the banks' authority in Indonesia as a reference in determining some policies relating to the state-owned banks' risks, efficiency, and inflation rates in Indonesia. Besides, this research also contributes to the literature concerning banking risks and efficiency.

The first section of this research will discuss the introduction, followed by the second section on literature review and hypothesis development. The third section of this research will explain the methodology employed in this research. The fourth section will present the regression analysis results and explain these results further in the discussion section. The conclusion becomes the last section in this research.

\section{LITERATURE REVIEW}

\section{Efficiency}

Efficiency is to produce maximum output from existing input. Traditionally, the assessment of banks' efficiency is calculated by the operating expenses ratio. This ratio compares operational costs with operating income (Haryanto, 2018). Banks incur operational costs in carrying out main business activities (interest, labour, and marketing costs). On the other hand, operating income is the banks' primary income, namely interest income obtained from the placement of funds in the form of credit and other operating placements (Sengkey et al., 2018). The higher this ratio, the lower the efficiency. 


\section{Credit Risk}

Credit risk is the risk due to the failure or inability of the debtor to return the loan amount obtained from the company along with interest in accordance with a predetermined period (Mosey et al., 2018). One of the indicators in measuring credit risk is the ratio of nonperforming loans (NPLs). This ratio measures how much banks face credit risk. The higher this ratio, the greater the risk of NPLs experienced by the bank. NPLs are classified into substandard loans, non-performing loans, and bad loans. Credit risk stemming from the expansion of credit resources can be reduced during periods of high economic growth, but this risk will increase slow economic growth (Li et al., 2021).

\section{Liquidity Risk}

Liquidity risk is a ratio used to measure the risk that banks will face if they fail to fulfil their obligations to their depositors with their liquid assets (Kasmir, 2018). Liquidity risk is the risk that investments cannot be traded quickly to minimise losses (Mazreku et al., 2019). According to Peraturan Bank Indonesia (2009), in Sengkey et al. (2018), liquidity risk is the banks' risk due to the inability of the banks to meet their maturing obligations from cash flow funding and or liquid assets without disturbing their daily activities. Liquidity risk can be measured using the liquidity ratio. This ratio consists of loan to deposit ratio, quick ratio, banking ratio, investing policy ratio, cash ratio, asset to loan ratio, investment portfolio ratio, and measurement of risks (Kasmir, 2018).

\section{Inflation}

Inflation is the rising prices of goods in general and is continuously caused by the decline in the value of money in a certain period (Bakti \& Alie, 2018). Based on its nature, inflation is divided into three categories, namely creeping inflation, galloping inflation, and hyperinflation (Sutawijaya \& Zulfahmi, 2012). Inflation control is vital; it aims to anticipate several things. First, inflation can worsen income distribution. Second, inflation causes a decrease in domestic savings, a source of funds investment for developing countries. Third, inflation causes a balance deficit trade and increases foreign debt. Fourth, inflation can cause political instability (Sutawijaya \& Zulfahmi, 2012).

\section{Hypothesis Development}

\section{Baking Risk and Efficiency Theoritical Basis}

\section{Bad Management Hypothesis}

The bad management hypothesis will explain the relationship between banking risks and efficiency. According to this hypothesis, risks and efficiency have an inverse relationship (Berger and DeYoung, 1997). This relationship means that an increase in risks will decrease efficiency, vice versa. Moreover, according to the bad management hypothesis, low efficiency indicates poor management (Saeed and Izzeldin, 2014). Lack of manager's monitoring results in higher risks, and this circumstance will decrease efficiency.

\section{The Relationship between Banking Risk and Efficiency}

Tan and Anchor (2017) discussed the relationship between risk-taking behaviour and efficiency in the Chinese banking industry. This risk-taking behaviour consists of liquidity, credit, capital, and insolvency risks. They revealed that liquidity risk has a negative and significant relationship with technical efficiency. Le (2018) examined the interrelationship among risks, capitalisation, and efficiency in the Vietnamese banking system. Le (2018) showed that banking risks have a negative and significant relationship with technical efficiency. Besides, Zeineb and Mensi (2018) also analysed the influence of banking risks on the efficiency of Gulf Cooperation Council (GCC) Islamic banks. They found that there is a positive influence on banking risks and efficiency. 
In conclusion, most previous studies, such as Salim et al. (2016), Tan and Anchor (2017), and Le (2018), showed that banks' risk has a negative relationship with efficiency. Indeed, according to the bad management theory, risks and efficiency have an inverse relationship. An increase in risks will decrease efficiency, vice versa. Hence, the first hypothesis in this research is as follows:

$\mathrm{H} 1$ : Banking risks has negative and significant influence on efficiency.

\section{Inflation as Moderator Variable}

\section{Theoritical Basis}

The Fisher effect theory is used in this study to explain the role of inflation as a moderating variable of the influence of bank risks on efficiency. This theory consists of nominal interest, expected inflation, and real interest rates (Zainal et al., 2021). The existence of inflation can affect bank interest rates (Sutawijaya \& Zulfahmi, 2012). Furthermore, fluctuations in interest rates can impact not only the level of risks (Campos, 2019; Linda et al., 2017) but also efficiency.

\section{The Relationship between Inflation and Bank Risk}

The relationship between banking risks and inflation rate as one of the macroeconomic factors has also been examined by many previous studies. Wiryono and Effendi (2018) discussed the effect of macroeconomic factors on Islamic banks' credit risk in Indonesia from 2010 to 2016. Macroeconomic factors were examined, such as inflation and gross domestic product (GDP). Wiryono and Effendi (2018) revealed that inflation has a negative and significant effect on the credit risk of Islamic banks in Indonesia. Azmi and Atirah (2018) analysed the influence of macroeconomic factors on risks in the Japanese banking sector from 2013 to 2017. They found that inflation as one of the macroeconomic factors has no significant influence on risk. Koju et al. (2018) examined the effect of macroeconomic factors on non-performing loans as one of the credit risk indicators. They examined 30 Nepalese commercial banks from 2003 to 2015. They revealed that inflation has a negative effect on non-performing loans. In addition, Fakhrunnas (2019) analysed the influence of macroeconomic factors on banks' risk of Islamic banks in Indonesia from 2014 to 2017. Their analysis result shows that inflation as part of macroeconomic factors has a negative and significant influence on banks' risk.

\section{The Relationship between Inflation and Banking Efficiency}

This study also identifies previous studies discussing the relationship between inflation and banking efficiency. Agade (2014) analysed the relationship between macroeconomic factors and banks' efficiency in Kenya banking sectors in 2013. Agade (2014) found a negative and significant relationship between inflation and efficiency. Sufian \& Kamarudin (2015) also examined factors that may affect the revenue efficiency of Islamic banks in Southeast Asian countries from 2006 to 2011. Their analysis revealed that inflation as one of the macroeconomic factors has a negative and significant effect on revenue efficiency. Besides, Kadar et al. (2016) analysed efficiency and determinant factors that may influence the efficiency of 43 Malaysian commercial banks from 2009 to 2013. They found that inflation as one of the determinant factors has a negative and significant influence on efficiency.

Based on previous studies above, inflation can influence not only banking risks but also banks' efficiency. Thus, the second hypothesis in this research is as follows:

H2: Inflation can moderate the relationship between banking risks and efficiency

\section{METHODS}

\section{Data}

Panel data analysis using ordinary least squares (OLS) is applied to measure the influence of banking risks on efficiency and the role of inflation as a moderating variable. The samples of this study are all state-owned banks in Indonesia. These banks are Bank Mandiri, Bank Negara 
Indonesia (BNI), Bank Rakyat Indonesia (BRI), and Bank Tabungan Negara (BTN). The financial data of state-owned banks is derived from the Indonesia Financial Service Authority website. Moreover, the inflation data comes from the Bank Indonesia website. Besides, this research uses quarterly data from 2016 to 2019.

\section{Operational Definition of Variables and Variable Measurements}

\section{Depedent Variable}

Table 1 shows the research variables and the measurements of all variables applied in this research. The dependent variable in this research is efficiency. The operating expenses ratio estimates the efficiency following Rosly and Abu Bakar (2003), Latif et al. (2016), and Salike and Ao (2018). This ratio is estimated by dividing operating expenses with operating revenue. It indicates that the higher this ratio, the lower banks can obtain efficiency.

\section{Independent Variables}

Moreover, liquidity risk will be estimated indirectly using the liquidity ratio. The liquidity ratio is calculated by loan to deposit ratio following Shingjergji and Hyseni (2015), Akhter and Kumar (2017), and Sudarmawanti and Pramono (2017). The ratio shows the banks' capability in providing loans to their borrowers by utilising their deposit funds (Sudarmawanti and Pramono, 2017). The higher the loan deposit ratio, the higher the liquidity risks.

Credit risk is estimated by credit ratio. According to Table 1, this ratio is estimated by the non-performing loans to total loans ratio following Simpasa (2015) and Tan and Anchor (2017). The higher the non-performing loans to total loans ratio, the higher the credit risk. An increase in the non-performing loans to total loans ratio indicates that there is an increase in the number of non-performing loans, and this circumstance will increase credit risk. On the other hand, a decrease in the non-performing loans to total loans ratio indicates a decrease in the number of non-performing loans leading to a decrease in credit risk.

\section{Moderating Variable}

Inflation as a moderating variable is calculated by the average of quarterly inflation from 2010 to 2014. Inflation is calculated by the differences between the current consumer price index and historical consumer price index divided by consumer price index times 100 (Koju et al., 2018).

\section{Control Variable}

Size can also affect efficiency (Widyasari \& Nataherwin, 2017; Le, 2018). Hence, this research also employs this variable as a control variable. This variable is estimated using the logarithm of total assets. 
Table 1. Variable Description

\begin{tabular}{|c|c|c|}
\hline Variable & Description & Previous Studies \\
\hline \multicolumn{3}{|c|}{ Dependent Variable } \\
\hline Efficiency & $\begin{array}{l}\text { Operating Expenses } \\
\text { Operating Revenue ratio }\end{array}$ & $\begin{array}{l}\text { Rosly \& Abu Bakar (2003), Latif et } \\
\text { al. (2016), Salike and Ao (2018) }\end{array}$ \\
\hline \multicolumn{3}{|c|}{ Independent Variable } \\
\hline Liquidity Risk & $\begin{array}{l}\text { Liquidity Ratio } \\
\text { Ratio of Loan to Total Deposit }\end{array}$ & $\begin{array}{l}\text { Shingjergji and Hyseni (2015), } \\
\text { Akhter and Kumar (2017), and } \\
\text { Sudarmawanti and Pramono (2017) }\end{array}$ \\
\hline Credit Risk & $\begin{array}{l}\text { Credit ratio } \\
\text { Ratio of non-performing loan } \\
\text { to total loans }\end{array}$ & $\begin{array}{l}\text { Simpasa (2015), and Tan and } \\
\text { Anchor (2017) }\end{array}$ \\
\hline \multicolumn{3}{|c|}{ Moderating Variable } \\
\hline Inflation & $\begin{array}{l}\text { (current consumer price index- } \\
\text { historical consumer price } \\
\text { index)/consumer price index } \\
\text { times ) } x 100 \text {. }\end{array}$ & Koju et al.(2018) \\
\hline \multicolumn{3}{|c|}{ Control Variables } \\
\hline Size & Logarithm of Total Assets & $\begin{array}{l}\text { Widyasari \& Nataherwin 2017; Le } \\
2018\end{array}$ \\
\hline
\end{tabular}

\section{Data Analysis}

This research applies panel data analysis using ordinary least squares (OLS) regression. OLS is employed in this research because this method is suitable for estimating the relationship between variables assumed to be stable in the cross-sectional unit (Gul et al., 2011). Furthermore, this research uses two regression models.

The first regression model is:

$$
\text { Efficiency }_{i t}=\beta_{0}+\beta_{1} \text { Liquidityrisk }_{i t}+\beta_{2} \text { Creditrisk }_{i t}+\beta_{3} \text { Size }_{i t}+\varepsilon_{i t}
$$

Equation (1) is the regression model simultaneously measuring the influence of banking risks on efficiency.

The second regression model is:

$$
\begin{aligned}
\text { Efficiency }_{i t}= & \beta_{0}+\beta_{1} \text { Liquidityrisk }_{i t}+\beta_{2} \text { Creditrisk }_{i t}+\beta_{3} \text { iinflation }_{i t}+\beta_{4} \text { Liqrisk.Inflation }_{i t} \\
& +\beta_{5} \text { Credrisk.Inflation }_{i t}+\beta_{6} \text { Size }_{i t}+ \\
& \varepsilon_{i t} \ldots \ldots \ldots \ldots \ldots \ldots \ldots \ldots \ldots \ldots \ldots \ldots \ldots \ldots \ldots \ldots \ldots \ldots \ldots \ldots \ldots \ldots \ldots \ldots \ldots \ldots \ldots \ldots \ldots \ldots \ldots \ldots \ldots \ldots \ldots \ldots \ldots \ldots \ldots \ldots \ldots \ldots
\end{aligned}
$$

Equation (2) is the regression model measuring the role of inflation as a moderating variable between banking risks and efficiency. In addition, multicollinearity and heteroscedasticity test is employed in this research prior to conducting the regression analysis.

\section{RESULTS}

\section{Descriptive Statistics}

Table 2 shows the descriptive statistics of all variables in this research. These variables consist of efficiency as the dependent variable, liquidity ratio and credit ratio as dependent variables, inflation as the moderating variable, and size as the control variable 


\section{Efficiency}

The average value of efficiency as a dependent variable is about 0.748 . The highest efficiency value is 0.98 , while the lowest is 0.63 . Meanwhile, the mean value of the efficiency ratio of private banks is about 0.78 . The maximum value of private banks' efficiency ratio is 0.6 , while the maximum value is 0.97 . The average value of these efficiency ratios calculated by operating expenses to operating revenue indicates that the inefficiency value of state-owned banks in Indonesia is still within the range determined by the bank authority.

\section{Liquidity Ratio as Independent Variable}

The liquidity ratio, calculated by the loan to deposit ratio, has a mean value of 0.95 . This value signifies that state-owned banks in Indonesia allocate $95 \%$ of their deposit funds into loans. The maximum value of liquidity ratio is 1.15 ; this value shows that there are banks distributing their fund over their total deposits funds. Meanwhile, the minimum value is 0.85 .

\section{Credit Ratio as Independent Variable}

Table 2 shows that the average value of state-owned banks' credit ratio estimated by nonperforming loans to total loans is about 0.028 . The minimum value of this government credit ratio is 0.017 . On the other hand, the maximum value of the credit ratio is 0.048 . The mean values of these state-owned banks are lower than 0.05 , meaning this value is still acceptable.

\section{Size as Cotrol Variable}

Furthermore, as a control variable, state-owned banks size has an average value of Rp

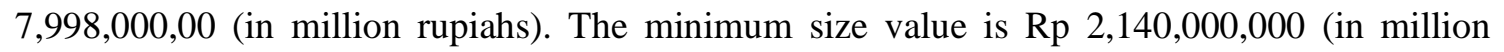
rupiahs), while the maximum size value is $R p 14,200,000,000$ (in million rupiahs).

\section{Inflation as Moderator Variable}

Inflation as a moderating variable has a mean value of 0.033 . The minimum inflation value is 0.025 , while the maximum value is 0.044 .

Table 2. Descriptive Statistics

\begin{tabular}{|c|c|c|c|c|}
\hline Variables & Observation & Mean & Minimum & Maximum \\
\hline Column 1 & Column 2 & Column 3 & Column 4 & Column \\
\hline Efficiency & 64 & 0.748 & 0.63 & 5 \\
\hline \multirow[t]{2}{*}{ Liquidity Ratio } & 64 & 0.95 & 0.85 & 0.98 \\
\hline & & & & 1.15 \\
\hline Credit Ratio & 64 & 0.028 & 0.017 & 0.048 \\
\hline $\begin{array}{l}\text { Size (in million } \\
\text { rupiah) }\end{array}$ & 64 & $7,998,000,00$ & $2,140,000,000$ & $14,200,000,000$ \\
\hline Inflation & 64 & 0.033 & 0.025 & 0.044 \\
\hline
\end{tabular}

\section{Diagnostic Test}

\section{Multicollinearity}

Table 3 shows the value of variance inflation factor (VIF) of dependent and control variables in this research. The VIF of liquidity ratio of state-owned banks is 2.76. Moreover, the VIF of state-owned banks' credit ratio is 1.15. Size as control variable has a VIF value of 2.77. Overall, the values of all of these variables are lower than 10. It means that there is no multicollinearity problem in this research. 
Table 3. Variance Inflation Factor

\begin{tabular}{lc}
\hline Variable & Variance Inflation Factor (VIF) \\
\hline Column 1 & Column 2 \\
Liquidity ratio & 2.76 \\
Credit Ratio & 1.15 \\
Size & 2.77 \\
\hline
\end{tabular}

\section{Heteroscedasticity}

The value of the Breusch-Pagan/Cook Weisberg test of state-owned banks is 0.867 , higher than 0.05 . Hence, the results show that the regression analysis is free from the heteroscedasticity problem.

\section{OLS Regression Result}

Table 4 and Table 5 show the OLS regression results of the influence of banking risks on efficiency. According to Table 4, the value of Adjusted R-squared is 0.760 . This value means that the influence of banking risks on efficiency is $76 \%$.

The liquidity ratio of state-owned banks in Indonesia has a coefficient value of 0.248 . The $\mathrm{t}$-statistics value is 2.88 , which is significant at $1 \%$. Hence these values indicate that the liquidity ratio of state-owned banks has a positive and significant influence on efficiency. The higher the liquidity ratio, the higher the liquidity risk. Indirectly, this result means that stateowned banks' liquidity risk positively and significantly influences efficiency.

The coefficient value of state-owned banks' credit ratio is 3.51 , while the t-statistic value is 4.46 . This t-statistic value is significant at $1 \%$. Hence, it means that the credit ratio of state-owned banks in Indonesia has a positive and significant influence on efficiency. Furthermore, credit ratio and credit risk have a positive relationship. Hence, indirectly, credit risk also positively and significantly influences efficiency.

According to Table 4, state-owned banks size as a control variable has a negative and significant influence on efficiency. The coefficient value of this variable is -0.056 , while the $t$ statistic value is -4.6 . This value is significant at $1 \%$.

\section{DISCUSSIONS}

\section{The Influence of Liquidity Risks on Efficiency}

The positive relationship between liquidity risk and efficiency is contrary to Tan and Anchor (2017). This positive relationship may occur because the increase in the loan to deposit ratio may increase efficiency. An increase in the loan to deposit ratio means that state-owned increase the allocation of their deposit funds into loans. As a result, this circumstance will increase stateowned banks' operating revenue and eventually increase efficiency. On the other hand, a decrease in the number of loans to deposit ratio means that state-owned banks decrease their allocation of deposit funds into loans. Hence, this circumstance may decrease banks' operating revenue and decrease efficiency.

\section{The Influence of Credit Risks on Efficiency}

Moreover, credit risk also has a positive and significant influence on efficiency. This positive relationship is consistent with Zeineb and Mensi (2018). An increase in credit risk causes many banks to increase their control and monitoring of their borrowers. It will increase the banks' monitoring costs, increasing their operating expenses. However, an increase in credit risk indicates that banks have increased their loan distribution. This circumstance may increase banks' operating revenue and potentially increase efficiency. Meanwhile, a decrease in credit risk indicates that banks decrease their loan distribution. A decrease in loan distribution not only may decrease banks' operating expenses but also decrease banks' operating revenue. As a result, a decrease in credit risk will also decrease efficiency. 
Table 4. OLS Regression Result

\begin{tabular}{|c|c|c|}
\hline Variable & $\begin{array}{l}\text { Coefficient } \\
\text { Estimates }\end{array}$ & t-statistics \\
\hline Column 1 & Column 2 & Column 3 \\
\hline $\mathrm{C}$ & 1.57 & $4.88 * * *$ \\
\hline Liquidity ratio (LDR) & 0.248 & $2.88 * * *$ \\
\hline Credit Ratio (NPLs) & 3.51 & $4.46 * * *$ \\
\hline Size & -0.056 & $-4.6^{* * * *}$ \\
\hline Adjusted R-squared & $0.760 * * *$ & \\
\hline
\end{tabular}

\section{Inflation as Moderator of The Relationship between Banking Risk and Efficiency}

Table 5 presents the OLS regression result for the influence of banking risks on efficiency and the role of inflation as a moderating variable. According to the table, inflation as a moderating variable has no significant influence on efficiency. This insignificant relationship is contrary to Agade (2014), Sufian \& Kamarudin (2015), and Kadar et al. (2016). This insignificant relationship may occur because inflation does not significantly affect state-owned banks' deposit and lending rates. Initially, the movement of inflation will influence the interest rate. However, state-owned banks have a high number of deposit funds with a low cost of funds. Thus, the movement of inflation may not significantly affect state-owned banks' cost of funds as one part of banks' operating expenses. As a result, inflation may not directly affect operating expenses or state-owned banks' revenue.

Moreover, Table 5 also shows that the coefficient value interaction between liquidity ratio and inflation of state-owned banks is -0.14 . However, the $t$-statistic value of this interaction variable is not significant. Therefore, inflation is unsuccessful to moderate the relationship between liquidity ratio and efficiency. This result also means that inflation cannot moderate the relationship between liquidity risk and efficiency. It may occur because stateowned banks have adequate funds for financing their liquidity. Even though there is inflation, state-owned banks do not face difficulties maintaining the increase in their cost of funds which eventually does not influence their operating expenses and operating revenue.

Furthermore, the interaction value between credit ratio and inflation of state-owned and private banks is also insignificant. The coefficient value of this interaction variable of stateowned banks is -0.461 , while the $\mathrm{t}$-statistic value is -3.10 . The $\mathrm{t}$-statistics value of this variable is significant at $1 \%$. Thus, this result shows that inflation can moderate the relationship between credit ratio and efficiency. This result indicates that inflation can moderate the relationship between credit risk and efficiency. The negative result of interaction between credit ratio and efficiency also means that inflation will decrease the relationship between credit risk and efficiency. The existence of inflation will affect banks' lending funds, and this circumstance will affect banks' credit risk. However, the existence of inflation may also increase banks' operating income. As a result, an increase in banks' operating income may decrease credit risk, and this circumstance may decrease the relationship between credit risk and efficiency. 
Table 5. OLS Regression Result

(Dependent Variable Efficiency)

\begin{tabular}{|c|c|c|}
\hline Variable & Coefficient Estimates & t-statistics \\
\hline Column 1 & Column 2 & Column 3 \\
\hline $\mathrm{C}$ & -0.416 & $-0.22 * * *$ \\
\hline Liquidity ratio (LDR) & -0.14 & -0.39 \\
\hline Credit Ratio (NPLs) & 19.57 & $3.75 * * *$ \\
\hline Inflation & 1.74 & 0.18 \\
\hline Liquidity Ratio*Inflation & 0.392 & 1.15 \\
\hline Credit Ratio*Inflation & -0.461 & $-3.10 * * *$ \\
\hline Size & -0.058 & $-4.71 * * *$ \\
\hline Adjusted R-Squared & $0.784 * * *$ & \\
\hline
\end{tabular}

Note: $\quad(*)$ indicates significance at $10 \%$ level, $(* *)$ indicates significance at $5 \%$ level, and $(* * *)$ indicates significance at $1 \%$ level

Source: Author's Calculation

\section{CONCLUSIONS AND SUGGESTIONS}

\section{Conclusion}

An increase in state-owned banks business operations may increase risks and decrease efficiency. Uncertainty in macroeconomic conditions may also affect banks' risk and their efficiency. Thus, this research examines not only the influence of banking risks on efficiency but also the role of inflation as a moderating variable from 2016 to 2019. OLS regression analysis shows that state-owned banks' liquidity and credit risks in Indonesia positively and significantly influence efficiency. However, inflation as a moderating variable has no significant effect on state-owned banks' efficiency. Moreover, this moderating variable cannot moderate the relationship between liquidity risk and efficiency of state-owned banks, but it can moderate the relationship between credit risk and efficiency.

\section{Suggestion}

Future research is expected to examine other macroeconomic factors, such as income levels and exchange rates, affecting the relationship between risks and banks' efficiency.

\section{Limitations}

Banks' efficiency is influenced by various factors, such as liquidity risk, interest rate risk, credit risk, total lending, total assets, and other factors. However, this study only discusses liquidity risk and credit risk. In addition, several macroeconomic factors, such as income levels, exchange rates, and gross domestic products, may affect the relationship between banks' risk and efficiency. However, this study only focuses on using inflation as a moderating variable.

\section{REFERENCES}

Agade, R. (2014). The effect of macroeconomic variables on operational efficiency of banking sector in Kenya. University of Nairobi.

Akhter, S., \& Kumar, J. (2017). Analysis of Credit Risk, Efficiency, Liquidity, and Profitability of Selected Non-Bank Financial Institution : An Empirical Study. Journal of Business, 02(02), 16-23. https://doi.org/10.18533/job.v2i2.70

Azmi, M., \& Atirah, N. S. (2018). The Factors Influence Credit Risk in Japan Banking Sector Specific for Kyoto Bank. Munich Personal RePEc Archive, 90566. https://mpra.ub.unimuenchen.de/90566/ 
Bakti, U., \& Alie, M. S. (2018). Pengaruh Inflasi dan Suku Bunga Terhadap Investasi di Provinsi Lampung Periode 1980-2015. Jurnal Ekonomi, 20(3), 275-285. https://ejournal.borobudur.ac.id/index.php/1/article/view/477

Berger, A. N., \& DeYoung, R. (1997). Problem loans and cost efficiency in commercial banks. Journal of Banking and Finance, 21(6), 849-870. https://doi.org/10.1016/S03784266(97)00003-4

Campos, M. F. (2019). Efektifitas kebijakan makroprudensial dan suku bunga SBI terhadap risiko kredit perbankan di Indonesia. Management and Business Review, 3(1), 23-32. https://doi.org/10.21067/mbr.v3i1.4733

Fakhrunnas, F. (2019). The Effect of macroeconomic and bank-specific variables to risk- taking of islamic bank in Indonesia. International Journal of Islamic Economics and Finance, 1(January), 165-186. https://doi.org/10.18196/ijief.129

Gul, S., Irshad, F., \& Zaman, K. (2011). Factors Affecting Bank Profitability in Pakistan. The Romanian Economic Journal, 14(39), 61-87.

http://www.rejournal.eu/sites/rejournal.versatech.ro/files/articole/2011-02-28/2101/guletalje39.pdf

Haryanto, S. (2018). Determinan Efisiensi Bank: Analisis Bank Di Indonesia. Accounting and Financial Review, 1(1), 46-52. https://jurnal.unmer.ac.id/index.php/afr/article/view/2230

Indonesia Financial Service Autority. (2015). Statistik Perbankan Indonesia (Indonesian Banking Statistics). Statistik Perbankan Indonesia, 13(2).

Kadar, A., Masum, M., Saona, P., \& Wanke, P. (2016). Bank efficiency in Malaysia : a use of malmquist. Eurasian Business Review, 7, 287-311.

Kasmir. (2018). Analisa Laporan Keuangan (11th ed.). Rajawali Pers.

Koju, L., Koju, R., \& Wang, S. (2018). Macroeconomic and Bank-Specific Determinants of Non-Performing Loans: Evidence from Nepalese. Journal of Central Banking Theory and Practice, 3, 111-138. https://doi.org/10.2478/jcbtp-2018-0026

Latif, Y., Abbas, A., Akram, M. N., Manzoor, S., \& Ahmad, S. (2016). Study of Performance Comparison between Islamic and Conventional Banking in Pakistan. European Journal of Educational and Development Psychology, 4(1), 17-33.

Le, T. D. Q. (2018). Bank risk, capitalisation and technical efficiency in the Vietnamese banking system. Australasian Accounting, Business and Finance Journal, 12(3), 41-61. http://dx.doi.org/10.14453/aabfj.v12i3.4

Li, R., Li, L., \& Zou, P. (2020). Credit risk shocks and banking efficiency: a study based on a bootstrap-DEA model with nonperforming loans as bad output. Journal of Economic Studies, 48(1), 1-19. https://doi.org/10.1108/JES-08-2019-0395

Mazreku, I., Morina, F., Misiri, V., Jonathan, \& Grima, S. (2019). Exploring the Liquidity Risk Factors in the Balkan Region Banking System. European Research Studies Journal, XXII(1), 96-108. https://doi.org/10.35808/ersj/1409

Mosey, A. C., Tommy, P., \& Untu, V. (2018). Pengaruh Risiko Pasar Dan Risiko Kredit Terhadap Profitabilitas Pada Bank Umum Bumn Yang Terdaftar Di Bei Periode 2012-2016. Jurnal EMBA: Jurnal Riset Ekonomi, Manajemen, Bisnis Dan Akuntansi, 6(3), 1338-1347. https://ejournal.unsrat.ac.id/index.php/emba/article/view/20217

Peraturan Bank Indonesia no. 11/25/PBI/2009 Tentang penerapan Manjemen Risiko bagi Bank Umum 
Rosly, S. A., \& Abu bakar, M. (2003). Performance of Islamic and mainstream banks in Malaysia. International Journal of Social Economics, 30(12), 1249-1265. https://doi.org/10.1108/03068290310500652

Saeed, M., \& Izzeldin, M. (2016). Examining the relationship between default risk and efficiency in Islamic and conventional banks. Journal of Economic Behavior and Organization, 132(S), 127-154. https://doi.org/10.1016/j.jebo.2014.02.014

Salike, N., \& Ao, B. (2018). Determinants of bank' s profitability : role of poor asset quality in Asia. China Finance Review International, 8(2), 216-231. https://doi.org/10.1108/CFRI-10$\underline{2016-0118}$

Salim, R., Arjomandi, A., \& Dakpo, K. H. (2016). Banks' efficiency and credit risk analysis using by- production approach : the case of Iranian banks. Applied Economics, 00(00), 1-15. http://dx.doi.org/10.1080/00036846.2016.1251567

Sengkey, J. I. B., Murni, S., \& Tulung, J. E. (2018). Analisis Faktor Â Faktor Yang Mempengaruhi Risiko Likuiditas Bank (Studi Kasus Pada Bank Umum Swasta Nasional Yang Terdaftar Di Bei Periode 2012-2015). Jurnal EMBA: Jurnal Riset Ekonomi, Manajemen, Bisnis Dan Akuntansi, 6(4), 3078-3087. https://ejournal.unsrat.ac.id/index.php/emba/article/view/21226

Shingjergji, A., \& Hyseni, M. (2015). The determinants of the capital adequacy ratio in the Albanian banking system during 2007 - 2014. International Journal of Economics, Commerce and Management, 3(1), 1-10. http://ijecm.co.uk/wpcontent/uploads/2015/01/3121.pdf

Simpasa, A. (2015). Bank lending channel in Zambia : empirical evidence from bank level data.

Sudarmawanti, E., \& Pramono, J. (2017). Pengaruh CAR, NPL, BOPO, NIM, dan LDR terhadap ROA (Studi Kasus pada Bank Perkreditan Rakyat di Salatiga yang terdaftar di Ototritas Jasa Keuangan Tahun 2011-2015). Among Makarti, 10(19), 1-18. http://dx.doi.org/10.52353/ama.v10i1.143

Sufian, F., \& Kamarudin, F. (2015). Determinants of revenue efficiency of Islamic Banks (Empirical evidence from the Southeast Asian countries). International Journal of Islamic and Middle Eastern Finance and Management, 8(1), 36-63. https://doi.org/10.1108/IMEFM$\underline{12-2012-0114}$

Sutawijaya, A., \& Zulfahmi. (2012). Pengaruh Faktor-Faktor Ekonomi terhadap Inflasi di Indonesia. Jurnal Ilmiah Manajemen Universitas Putera Batam, 8(2), 85-101. https://jurnal.ut.ac.id/index.php/jom/article/view/237

Tan, Y., \& Anchor, J. (2017). The Impact of risk-taking behaviour and competition on technical efficiency: evidence from the Chinese banking industry. Research in International Business and Finance, 41, 90-104. https://doi.org/10.1016/j.ribaf.2017.04.026

Wiryono, S. K., \& Effendi, K. A. (2018). Islamic Bank Credit Risk : Macroeconomic and Bank Specific Factors. European Research Studies Journal, XXI(3), 53-62. https://doi.org/10.35808/ersj/1043

Zainal, N., Bakri, M. H., Hook, L. S., Zaini, S., Faizal, M., \& Mara, U. T. (2021). Validity Of Fisher Effect Theory: Evidence from The Conventional and Islamic Money Market in Malaysia. Quality - Access to Success, 22(184). h

Zeineb, G. Ben, \& Mensi, S. (2018). Corporate governance, risk and efficiency : evidence from GCC Islamic banks. Managerial Finance, 44(5), 551-569. https://doi.org/10.1108/MF-052017-0186 